\title{
Decolonising the decolonisers? Of ontological encounters in the GMO controversy and beyond
}

\author{
Doerthe Rosenow \\ Senior Lecturer in International Relations \\ Oxford Brookes University \\ drosenow@brookes.ac.uk
}

\begin{abstract}
:
Calls for decolonising IR are often focused on the need to decolonise dominant epistemologies. This article explores whether a shift towards decolonising ontology is able to provide a more profound challenge. Decolonising ontology implies acknowledging that there are multiple actual "worlds", rather than just multiple perspectives on THE ("one") world. However, I argue that this approach is limited by the representational strategies that are used for making the encounter of multiple worlds legible for an academic audience. Drawing on ethnographic work that anthropologists have undertaken in relation to the GMO controversy as well as broader decolonial work in IR, I maintain that the writing-up of research often entails the settling and stabilising of ontological encounters that have been experienced as unsettling and disconcerting. This move towards stabilisation is grounded in hegemonic, colonial understandings of which questions should be pursued and why: questions that continue to be about determining what "is" (rather than asking what questions would lead to rightful action), that can be answered with the help of allencompassing concepts (such as the concept of the "pluriverse"), and that provide insights for entire disciplines (such as IR). The article shows to what extent this is detrimental to projects of decolonisation.
\end{abstract}




\section{Introduction}

No translation would be capacious enough to allow me to know certain practices. I could translate them, but that did not mean I knew them... when I turned those practices or words into what I could grasp, that - what I was describing - was not what those practices did, or what those words said.

Marisol de la Cadena, 2015

Since the start of the prominent campaign to 'decolonise the university' at the University of Cape Town in March 2015 and its consequent spreading to European universities and around the world, there has been a proliferation of 'decolonising' conference papers, articles, panels and indeed entire conferences, including in the discipline of International Relations (IR). 1 At the same time, critical voices have started to appear around this 'buzz' of decolonisation in the academy. Eve Tuck and K. Wayne Yang warn of the danger of turning decolonisation into a 'metaphor' that renders invisible, in its focus on knowledge production, Indigenous struggles around demands for land repatriation.2 Silvia Rivera Cusicanqui makes a similar critique of decolonial theorist Walter D. Mignolo, who, she claims, is squarely sitting in the Western economy of knowledge production, remote from actual Indigenous practice on the ground. 3 Likewise, in a recent article Karen Tucker argues that decolonial IR has the tendency to depict regimes of 'coloniality' (a term coined by Latin American decolonial thought) as 'uniform, unitary systems of oppression and domination'. This is because the literature suffers from a lack of 'closed, detailed analysis of the dispersed practices that produce racialized hierarchies and erasures.' 4

This article agrees that there is need for more detailed ethnographic work that unravels the nuances, complexities and specificities of contemporary colonial practices, and that takes into account the actual demands and practices of existing decolonial struggles at concrete sites. This is particularly relevant for a discipline such as IR that has traditionally not encouraged this kind of work. However, I argue that there is a further problem, which is not about what is concretely studied and where, but about how research is made legible for an academically literate and interested audience. I maintain that calls for decolonisation are jeopardised by having to bow to what is expected of academic work: namely to produce general insights that are able to move beyond the concreteness of a situation, and to do so with a level of stringency and coherence that enable readers to 'take home' clearly demarcated conclusions that can be 'applied' elsewhere. These expectations, which are intimately bound to hegemonic, colonial modes of knowledge production, are at odds with other, non-European 'grounded normativities's which might be driven by entirely different

1 See e.g. Peter Ruddock, "Decolonising Education in South Africa", 9 Mar 2018, available at: https://www.iol.co.za/news/opinion/decolonising-education-in-south-africa-13679313; Gurminder K. Bhambra, "To Decolonise the University Is to Democratise the University", Times Higher Education, 27 Sep 2018, available at: https://www.timeshighereducation.com/opinion/decolonise-university-democratise-university. For a comprehensive overview of related work in IR, see Karen Tucker, "Unraveling Coloniality in International Relations: Knowledge, Relationality, and Strategies for Engagement", International Political Sociology, Vol. 12, No. 3 (2018), pp. 215-232.

2 Eve Tuck and K. Wayne Yang, "Decolonisation Is Not a Metaphor", Decolonization: Indigeneity, Education \& Society, Vol. 1, No. 1 (2012), pp. 1-40.

3 Silvia Rivera Cusicanqui, "Ch'ixinakax utxiwa: A Reflection on the Practices and Discourses of Decolonization", The South Atlantic Quarterly, Vol. 111, No. 1 (2012), pp. 95-109.

4 Tucker, op.cit., p. 216.

5 Leanne Betasamosake Simpson, As We Have Always Done: Indigenous Freedom through Radical Resistance (Minneapolis: University of Minnesota Press, 2017), pp. 22-25; drawing on the work of Glen Coulthard for that term. 
needs and questions. 6 While this incommensurability is acknowledged and affirmed in decolonial scholarship, I argue that the latter often ignores the impact it has on academic writing practices and objectives themselves: the questions that are pursued, the way an argument is developed, and the structure an article or book must adhere to.

One way to potentially avoid this problem and to properly acknowledge incommensurability lies in a shift of focus from the question of how to decolonise knowledge to how to decolonise being. 7 For decolonial theorist Walter D. Mignolo decolonisation crucially involves thinking differently - thinking at the 'border', as he calls it, drawing on the work of Gloria E. Anzaldúa.8 It is a conceptual project that makes it relatively easy for existing critical conceptual work to incorporate it as a new, but yet not-quite-so-different modality of critique. By contrast, IR scholar Cristina Rojas, as well as other scholars who draw on what is often called the 'ontological turn' in anthropology, argue that radical difference needs to be located at the level of ontology. This means that we need to acknowledge the existence of multiple, different worlds, rather than merely accepting multiple perspectives on THE ('one') world. Ontological multiplicity needs to be encountered rather than conceptualised: it comes about when we encounter the clashing of different worlds, which is necessarily unsettling, disconcerting and dislocating.9 According to Rojas, a turn to ontological rather than epistemological difference would lead to a 'politics of pluriversality' that is 'premised on deep relational ontologies between humans, and humans and nature'. This, she maintains, would more fundamentally disrupt the modern 'one nature/multiple cultures' dichotomy than Mignolo's emphasis on how to produce different knowledge. 10 Using the terminology of this special issue, the turn towards ontology could be called a turn towards affirmation: it strives towards an affirmation of the plurality and complexity of what is, and it sees potential for creating new, emancipatory projects out of the unsettling and often uncomfortable encounters of that plurality. 11

This article explores to what extent this shift towards decolonising ontology that involves the acknowledgement of ontological multiplicity is able to challenge hegemonic, colonial modes of academic knowledge production. The potential of this move lies in its focus on the unsettling character of ontological encounters, and the politics and ethics that emerge from that. This is particularly pertinent for Western scholars who actively need to seek ontological encounters. As Kwakwaka'wakw geographer Sarah Hunts points out, Indigenous scholars like herself have to navigate the 'tension' that results from having to move between different worlds out of necessity, while non-Indigenous people 'interested in engaging with Indigenous ontologies' need to open up to practices and experiences that might make them, as 'witness' and 'listener', 'unhinged' and 'uncomfortable'.12 While this is precisely what is advocated by decolonial scholars following the ontological turn, the question emerges what 'representational strategies' they then use to make 'legible' that what has been encountered.13 As I will show in the next section, if these strategies lead to stabilisation

66 Cf. Sarah Hunt, "Ontologies of Indigeneity: the Politics of Embodying a Concept", Cultural Geographies, Vol. 21, No. 1 (2014), pp. 27-32.

7 Cf. Nelson Maldonado-Torres, "On the Coloniality of Being: Contributions to the Development of a Concept", Cultural Studies, Vol. 21, No. 2-3 (2007), pp. 240-70.

8 Walter D. Mignolo, Local Histories/Global Designs: Coloniality, Subaltern Knowledges, and Border Thinking. Paperback reissue with a new preface, 2012 (Princeton: Princeton University Press, 2000), p. 161.

9 Cristina Rojas, "Contesting the Colonial Logics of the International: Toward a Relational Politics for the Pluriverse", International Political Sociology, Vol. 10, No. 4 (2016), p. 377.

10. Ibid., p. 369.

11 Pol Bargués-Pedreny, "From Critique to Affirmation in International Relations", Global Society, Vol. 33, No. 1 (2019).

12 Hunt, op.cit., p. 31.

13 Ibid., p. 28. 
rather than destabilisation - and this is precisely what happens in some of the decolonial ontological turn literature in IR - the project of decolonisation is yet again undermined.

After having made this argument in section two, the article will then, in section three, analyse two ethnographic texts on anti-genetically modified organisms (GMO) activism that engage with the GMO controversy in relation to smallholder producers in Paraguay and Mexico respectively. I have chosen the example of the GMO controversy as illustration for this article because of the strong emphasis that the ontological turn literature places on the need to overcome the crucial nature/culture dichotomy of modern ontology. As I will indicate, at the core of the debate around GMOs lies the central question of what counts as 'natural' and what as 'cultural', and what should matter more when making decisions about the morality, benefits and harm of products of agricultural biotechnology. While different argument are possible within that frame, underlying all of this is the tacit understanding that 'nature' is ONE (leading to arguments about what we know or don't know about 'it'), while people might have different (cultural) perspectives on what should matter in relation to it. The two texts that are analysed in section three provide a particularly strong sense of unease and grappling in relation to this tacit frame, but also yet again a framework that allows for this discomfort to be accommodated and thereby settled.

Turning back to the generic literature on the ontological turn and decolonial thought in the last section of this article, I will further contemplate on how this pull towards the general and abstract manifests itself, and how it differs from other systems of sense-making. This article will not provide a conclusion; precisely because a conclusion is usually the place in which the pull towards establishing clearly delineated and coherent 'take home' insights is particularly strong. Drawing on reflections provided by Cherokee philosopher Brian Yazzie Burkhardt, I ask which questions matter to critical scholars and why (in IR and beyond), and what sort of different 'representational strategies' are available that can help Western scholars to contribute to decolonisation.

\section{Decolonial thought and the problem of ontology}

Decolonial scholars understand the colonial project as co-constitutive of the project of modernity as such. Quijano introduced the term 'coloniality of power' in his 1989 foundational text in order to contrast it to the term 'colonialism', which is meant to describe 'an explicit [historical] political order'.14 The concept of coloniality signifies the 'extension of Western capitalism' and the parallel 'extension of Western epistemology' to the nonEuropean world from the $15^{\text {th }} / 16^{\text {th }}$ century (the conquering of the Americas and 'the emergence of the Atlantic commercial circuit') 15 which, it is argued, is ongoing today. 16 Because of the process of co-constitution, the beginning of modernity 'proper' likewise needs to be located in the $15^{\text {th }} / 16^{\text {th }}$ century and not, as it is often done, in the $18^{\text {th }}$ century. Otherwise 'coloniality' becomes merely 'derivative'; serving to reaffirm modernity's claim to be all-inclusive and universal, erasing or relegating the 'Iberian foundational period of capitalist expansion and coloniality...to the Middle Ages as the Black Legend'.17

Because of the crucial epistemological dimension of the modernity/coloniality project, decolonisation needs to include the decolonisation of knowledge, which for Mignolo needs

14 Aníbal Quijano, "Coloniality and Modernity/Rationality", Cultural Studies, Vol. 21, No. 2-3 (2007), p. 170. 15 Walter D. Mignolo, "The Geopolitics of Knowledge and the Colonial Difference", South Atlantic Quarterly, Vol. 101, No. 1 (2002), pp. 58-59.

16 Quijano, op.cit., p. 170.

17 Mignolo, 'Geopolitics of Knowledge', op.cit., p. 61. 
to happen through the Global South having to 'de-link' from Western modes of knowledge production. 18 The decolonising task lies in a move towards 'the re-construction and restitution of silenced histories, repressed subjectivities, subalternized knowledges and languages performed by the Totality depicted under the names of modernity and rationality.' ${ }_{19}$ Using the terminology of this special issue, it could be argued that decolonial thought is a project of affirmation, at least if the latter is not only understood as 'grasp[ing] the thing by the root' (as Marx envisaged) but as 'tend[ing] to a different plant altogether.' 20 For decolonial scholars, this different 'plant' is emerging from the other side of what Mignolo calls the 'colonial difference', which is the 'difference between center and periphery, between the Eurocentric critique of Eurocentrism and knowledge production by those who participated in building the modern/colonial world and those who have been left out of the discussion.' 21 At the same time, the call for generating different knowledges and ways of being emerges from a universal historical, political and economic analysis of 'the modern/colonial world system'.22 In other words, decolonial thought is also grounded in a project of critique, if the latter is understood as providing an analysis of actual (historical) structures of domination.

Lucas Bessire and David Bond use the metaphors of 'roots' and 'plants' to outline what lies at the heart of the ontological turn in anthropology, and to show how it differs from other intellectual projects.23 Those following the ontological turn argue that the universal aspirations of modern ontology, and particularly the latter's grounding in the onenature/multiple-cultures dichotomy, needs to be challenged and replaced with an understanding of worlds as ontologically plural; making space for other peoples' (e.g. Indigenous) understandings of what is real. However, as Zoe Todd argues, one of the key problems of this approach is that it tends to forget what has led to the universalisation of modernity in the first place: colonialism.24 For Latour, modernity kickstarted with the Cartesian 'Cogito ergo sum', while for decolonial philosopher Enrique Dussel it all began with the 'Cogito ergo conquiro': 'the enactment of the Western self as conqueror'. 25 In other words, the modern subject/object dichotomy is intrinsically linked to the logic of coloniality: it rests on a singular logic and pathway for 'the' (one) world that provides a justification for the silencing and eradicating of other worlds.

18 Walter D. Mignolo, "Delinking: The Rhetoric of Modernity, the Logic of Coloniality and the Grammar of Decoloniality", Cultural Studies, Vol. 21, No. 2-3 (2007), pp. 449-514.

19 Ibid., p. 451.

20 Lucas Bessire and David Bond, "Ontological Anthropology and the Deferral of Critique", American Ethnologist, Vol. 41, No. 3 (2014), p. 445. For similar analyses and critique, see in this issue: David Chandler, "The Transvaluation of Critique in the Anthropocene", Global Society, Vol. 33, No. 1 (2019); Pol Bargués-Pedreny and Jessica Schmidt, "Learning to Be Postmodern in an All Too Modern World: 'Whatever Action' in International Climate Change Imaginaries" Global Society, Vol. 33, No. 1 (2019); Kai Koddenbrock and Mario Schmidt, "Against Understanding: The Techniques of Shock and Awe in Jesuit Theology, Neoliberal Thought and Timothy Morton's Philosophy of Hyperobjects", Global Society, Vol. 33, No. 1 (2019).

21 Mignolo, "Geopolitics of Knowledge", op.cit., p. 63. It needs to be emphasised that I am not maintaining that this is how the ones described by Mignolo as 'left out' would necessarily themselves describe their position or role.

22 Mignolo, Local Histories, op.cit., p. 74.

23 Bessire and Bond, op.cit.

24 Zoe Todd, "An Indigenous Feminist's Take on the Ontological Turn: 'Ontology' Is Just Another Word For Colonialism", Journal of Historical Sociology, Vol. 29, No. 1 (2016), pp. 4-22.

25 David L. Blaney and Arlene B. Tickner, "Worlding, Ontological Politics and the Possibility of a Decolonial IR", Millennium, Vol. 45, No. 3 (2017), pp. 298; referring to Enrique D. Dussel, Javier Krauel and Virginia C. Tuma, "Europe, Modernity, and Eurocentrism", Nepantla: Views from the South, Vol. 1, No. 3 (2000), pp. 465-478. See also Angela Last, 'Anti-colonial Ontologies: A Dialogue', in Mark Jackson (ed.), Coloniality, Ontology, and the Question of the Posthuman (London and New York: Routledge, 2018), pp. 63-80. 
This shows how decolonial critique can be useful to tease out problems of the ontological turn literature (or projects of affirmation more generally). However, it also works the other way round. 26 As Rojas argues, and as already indicated in the introduction of this article, some of the 'founding fathers' of the decolonial approach do not pay sufficient attention to the question of ontology. Mignolo's colonial difference remains at its core an epistemological one: it is about different representations of 'the' (one, real) world. 27 Likewise, Dussel's call for a 'world dialogue' that can lead to 'a global trans-modern pluriverse' is located at the conceptual level: it is about a conversation between different conceptualisations of 'the' world.28 This leaves the modern nature/culture divide intact: Difference is located at the level of 'culture', while nature remains something external - an object - that can be known. To say it with Rojas: human knowledge continues to 'trump[...] ontology'.29

According to Rojas, an actual acknowledgment of the existence of ontological multiplicity would need a very different dialogue: one that is a relational 'activity of openness to the other' that can never be abstract, and that encounters rather than attempts to know radical difference; leading to constant displacement of and discomfort for the one who seeks to know. 30 The 'politics of pluriversality' that emerge from this are 'emergent and distinct' insofar that they are 'premised on deep relational ontologies between humans, and humans and nature': 31 unsettling and uncomfortable, but at the same time emancipatorydecolonising. 32

What this may concretely entail is very well captured in the ethnographic reflections of Marisol de la Cadena with which I have begun this article:

[N]o translation would be capacious enough to allow me to know certain practices. I could translate them, but that did not mean I knew them...The practices were what my friends did, and the words were what they said; but what those practices did or what those words said escaped my knowing. Of course I described them in forms that I could understand; but when I turned those practices or words into what I could grasp, that - what I was describing - was not what those practices did, or what those words said. 33

Engaging in what de la Cadena calls 'co-laboring' with those who are in relationships with beings (which she calls 'earth-beings') that cannot be known by herself leads to 'excess as important ethnographic condition and analytical challenge': a performance that goes 'past the limit' of what could be grasped from within her existing epistemological framework. 34 The result are unavoidable misunderstandings that, however, ' $d[0]$ not fully inform us about "the stuff" that compose[s] those misunderstandings.' 35

These reflections lead Rojas and other authors in IR who draw on both ontological anthropology and decolonial thought to emphasise the need for exposing oneself to such

\footnotetext{
26 On the complementarity and tensions between post- and decolonial as well as Indigenous literature on the one hand, and literature of the ontological turn, posthumanism and the New Materialisms on the other, see Mark Jackson (ed), Coloniality, Ontology, and the Question of the Posthuman (London and New York: Routledge, 2018).

27 Rojas, op.cit., p. 377.

28 Enrique Dussel, "A New Age in the History of Philosophy: The World Dialogue between Philosophical Traditions", Philosophy \& Social Criticism, Vol. 35, No. 5 (2009), p. 499.

29 Rojas, op.cit., p. 377.

30 Ibid., quoting the writings of Claudia De Lima Costa and drawing on Marisol de la Cadena.

31 lbid., p. 369.

32 Ibid., p. 380; cf. Marisol de la Cadena, Earth Beings: Ecologies of Practice Across Andean Worlds (Durham:

Duke University Press, 2015), p. 63.

33 de la Cadena, op.cit., p. 3.

34 Ibid., pp. 14, 63.

35 Ibid., p. 63; see also Rojas, op.cit., p. 378.
} 
encounters, and the conflicts that those encounters inevitably entail. David L. Blaney and Arlene B. Tickner, for example, argue that we need to 'walk[...] with peoples and places in deep relation'; cultivating rather than producing knowledge. 36 The authors note what this means for the discipline of IR, which needs to become 'pluriversal' so that it can examine how the outlining of specific problems and of the right courses of political action need to be seen in the context of particular ontologies. 37 Rojas similarly concludes that international politics needs to advance a political project of pluriversality in order to be able to respond 'to the urgent global problems that modernity has created and cannot solve, including climate change, monocrop agriculture, perpetual accumulation, and the will to "progress" at all costs.' 38

Despite the force and importance of this argument, I have felt slightly uneasy when reading those conclusions. Focusing on radical ontological difference can easily lead to a romanticised reification of other peoples' difference that is in danger of ignoring actual political struggles and demands on the ground. As Cusicanqui argues, those struggles might very well emerge out of an 'indigenous modernity', rather than an insistence on the right to one's difference. By this she means that some Indigenous people aim to formulate a hegemonic vision for how to structure a society that is valid for everyone (Indigenous AND non-Indigenous): they work for a society that is in their 'image and likeness', and to use modern notions such as 'citizenship' for this purpose, rather than rejecting the latter as irreconcilable with one's own world. 39 By contrast, some North American Indigenous intellectuals call for an Indigenous 'resurgence' that, rather than seeking hegemony, altogether turns away from seeking recognition by wider (colonial) 'society'. As Leanne Betasamosake Simpson points out, in such 'resurgent mobilization...there is virtually no room for white people'.40

But my unease was also emerging from something else, which is what I want to focus on in this article: the problem that encounters and conflicts are yet again made sense of within overarching structures of knowledge production rather than cultivation (despite the intention to do otherwise). As de la Cadena herself makes clear in the quotation above, what is encountered as 'different' is inevitably described 'in forms that I could understand' (my emphasis) - even whilst simultaneously recognising that one's description does not capture what the encountered practices actually do. Sense-making, for de la Cadena, takes place at what could be called two levels: At a first level, there is the inevitable process of making sense of an alienating affective experience on the spot, from within one's own framework of understanding the world. At a second level, then, de la Cadena attempts to make legible her grappling and not-understanding in the context of a book for an academically literate and interested audience - in other words, in the writing-up of her ethnographic research.

In Rojas' and Blaney and Tickner's case, given that their articles do not aim to make an empirical contribution, sense-making takes place at what could be called a third level: what is drawn upon is the understanding that emerged out of the ethnographic work of others, which is brought into conversation with various bodies of theoretical work in order to make a conceptual contribution. This takes place via the coining of central concepts and the outlining of all-encompassing frameworks that are meant to help us understand the

36 Blaney and Tickner, op.cit., p. 308; referring to the work of Robbie Shilliam.

37 Ibid., p. 310.

38 Rojas, op.cit., p. 380.

39 Cusicanqui, op.cit., p. 106. Note though that her critique is directed against decolonial thought (particularly the work of Mignolo), and not against the ontological turn literature.

40 Simpson, op.cit., p. 228. Not all authors who make the argument about ontological encounters are necessarily white - but the point is they are making claims about wanting to engage in ontological encounters from a scholarly position that is very much based in Western modernity. 
analytical, normative and political consequences of their argument for scholarly work more broadly. The ontological encounters of others are used to delineate the merits of ontological encounters in general, in IR and beyond. This objective leads to a particular way of developing and structuring a generic argument that makes it difficult to move beyond sensemaking frameworks that are necessarily geared towards settling all those unsettling and disconcerting experiences that were the focus of the articles in the first place.

This is also the problem of some central decolonial work. Drawing on Edouard Glissant, Mignolo, for example, critiques the 'requirement of transparency' that forms the basis for understanding in Western social science scholarship. He argues for the 'right to opacity' of those located on the other side of the colonial difference.41 But this claim sits at odds with his simultaneous desire to write a new, all-encompassing history of 'the modern/colonial world system'. 42 And like in Rojas' and Blaney and Tickner's articles, terms such as 'pluriversality' 43 or 'diversality' 44 are coined in order to have a (one!) concept for a similarly all-encompassing solution to domination. While de la Cadena is critical of her own 'anxiety to understand coherently (with which I meant clearly and without contradiction'), and while she points out how this 'was often out of place', 45 Mignolo as well as Rojas and Blaney and Tickner seek to place such anxiety in yet another coherent framework that holds everything together.

The question arises whether this can be any different in scholarly work that is not directly based on ethnographic research itself, and which can therefore not lay claim to a direct experience of ontological controversies. This has become an important question for my own (likewise third-level) work on anti-GMO activism. My work to date has primarily aimed at making a conceptual contribution, and has relied on a conversation between the ethnographic research of others and various bodies of conceptual work, including decolonial and 'ontological turn' literature. 46

But as I have already indicated in relation to de la Cadena's work, when writing up their research for academic purposes, even those who have directly experienced ontological encounters find it hard to resist the tendency to conclude their work with stringent, overarching, coherent conclusions that the Western-educated reader can grasp and 'take home'. In the next section, I will draw on two anthropological ethnographic texts that are significant for research on the GMO controversy to show how this works. The two texts that will be analysed in the next section engage with the GMO controversy in Paraguay and Mexico respectively, and they have stood out for me in the way they manage to convey a sense of unease and grappling with ontological encounters and conflicts. However, as the next section will show, they as well end up providing a framework and conclusions that can accommodate and make sense of the encountered ontological difference.

\section{Ontological encounters in the GMO controversy}

According to Susana Carro-Ripalda and Marta Astier, much of the research that is carried out in relation to the question of what smallholder producers in the Global South truly think of

\footnotetext{
41 Mignolo, Local Histories, op.cit., pp. 81, 76.

42 Ibid., p. 74.

43 lbid., p. xiv.

44 Ibid., p. 246.

45 de la Cadena, op.cit., p. 54

46 See for example Doerthe Rosenow, Un-making Environmental Activism: Beyond Modern/Colonial Binaries in the GMO Controversy (London and New York: Routledge, 2018); Leonie Ansems de Vries and Doerthe Rosenow, "Opposing the Opposition? Binarity and Complexity in Anti-GMO Activism", Environment and Planning D, Vol. 33, No. 6 (2015), pp. 1118-1134.
} 
(and say about) agricultural biotechnology is unable to grasp the 'ontological incompatibility' that exists between the experienced human/nonhuman relations in small-scale agriculture on the one hand, and the logic that underlies genetic engineering (GE) on the other. 47 This is precisely because most social research is itself grounded in the crucial modern/colonial nature-culture divide: the former can only be known through scientific means, while the latter can be known through the study of social/cultural/political practices. Knowledge about nature is about establishing 'facts', which are either true or false (i.e. nature as 'one' is either correctly or incorrectly represented), while knowledge about culture is about studying meaning, which is necessarily (due to the existence of different cultures) multiple.

The question of whether GMOs do or do not pose a 'factual' danger consequently lies outside of the remit of the social sciences, which therefore focus on the social dimension of statements that are made about nature. But as Kregg Hetherington's reflections on his own anthropological research journey in Paraguay make clear, this tacit signing-up to modern ontology can lead to difficulties in understanding the reality of the people one is interested in. 48 Coming from a position in which he took for granted the scientific distinction between (proven) 'fact' and 'error', Hetherington explains how he 'translate[d]' the claims of the leader of a local peasant movement 49 (Antonio) about the truth of (GM) soy 'killer beans' into something else:

'Until this point, I had approached ethnography as an extended discussion with and about humans, and I was less interested in beans than I was with what Antonio said about them...To be blunt, Antonio kept pointing at the beans, and I kept looking at him...I was comfortable saying that this was a figure of speech, a kind of political rhetoric, or even to claim that this is what Antonio believed, all of which explicitly framed 'la soja mata' (soy kills) as data for social analysis, rather than analysis itself worthy of response.' 50

However, Hetherington points out that not believing in the truth of the killer bean did not prevent him from 'participating in Antonio's knowledge practices'. 51 Becoming involved in the anti-soy bean activism of the peasants, Hetherington became 'part of the situation' that made the killer bean turn into a crucial agent in a court case that was brought against two soy farmers for the murder of two activist peasants. As a result, killer beans became transformed into a matter of national concern. Crucially for Hetherington, participation involved more than joining the situation in spite of his lack of belief: it led to him becoming immersed in a relation with both peasants and beans that started to have a physical impact on him - in de la Cadena's words, he indeed became 'partially connected': 52

'Beans didn't scare me at first. Indeed, as a foreigner to the situation that gives rise to killer beans (a Canadian no less), giant fields of soy were a familiar, even a comforting sight. But it took only a few months with Antonio for me to start feeling the menace from those fields. Soon, the sweetish smell of glyphosate, recently applied, and especially the corpselike smell of 2, 4-D mixed with Tordon, could ruin my appetite and make me expect to see people emerge from their homes to show me pustules on their legs and stomachs.' 53

47 Susana Carro-Ripalda and Marta Astier, "Silenced Voices, Vital Arguments: Smallholder Farmers in the Mexican GM Maize Controversy", Agriculture and Human Values, Vol. 31, No. 4 (2014), p. 659.

48 Kregg Hetherington, "Beans Before the Law: Knowledge Practices, Responsibility, and the Paraguayan Soy Boom", Cultural Anthropology, Vol. 28, No. 1 (2013), pp. 65-85.

49 In Latin America, Indigenous people sometimes distinguish themselves from peasant movements, because of a past in which leftist movements did not allow for a distinct Indigenous identity and instead steamrolled them into a general 'peasant' identity (see e.g. de la Cadena, op.cit., for how this played out in Peru). However, this section follows the signifiers used by the ethnographers themselves, because the point is to understand their grappling with what they themselves encountered as ontological difference.

50 Hetherington, op.cit., p. 67; emphasis in original.

$51 \mathrm{lbid}$.

52 de la Cadena, op.cit., p. 3, drawing on Marilyn Strathern.

53 Hetherington, op.cit., p. 72. 
Similar observations are also found in Carro-Ripalda and Astier's contribution to the 2014 Agriculture and Human Values symposium on the challenges of making smallholder producer voices being heard in relation to agricultural biotechnology. 54 While most of the contributions to the symposium concentrate on how to tease out smallholders' 'real' voices in the most effective way, Carro-Ripalda and Astier critically reflect on their own perceived failure to become knowledgeable about smallholders' voices in their research on GM maize cultivation in Mexico.

It was through ethnographic fieldwork in rural areas in Central Mexico, in-depth structured interviews, focus groups, participant observation and, finally, a National Workshop in Mexico City with over 50 stakeholders (including smallholder producers) that Carro-Ripalda and Astier attempted to get a better sense of what the actual voices of peasants in the GM controversy were trying to convey. 55 However, particularly the final workshop, which aimed to create conditions under which Mexican smallholder producers could speak on their own terms about GM maize cultivation, 'unwittingly reproduced the conditions of exclusive, techno-scientific and regulatory spaces'. 56 The public discourse that centres on questions of safety, science, possibilities of regulation and problems of potential contamination, and which is upheld by both GM maize proponents and anti-GMO activists, dominated the workshop debate. Even when present smallholders raised different concerns, the discussion always returned to the previous, main ones, as if those who had spoken differently 'had not spoken at all'. The way that smallholders could articulate 'their perceptions, ideas, and desires' was thereby 'severely limited'. 57

Carro-Ripalda and Astier are focused on the dominance of one particular (techno-scientific, regulatory) discourse that, they maintain, disabled smallholder voices engaged in different discourses from speaking up or, when speaking, from being heard. In other words, smallholders were unable to adequately represent their own understanding of what is at stake in the GM maize controversy in Mexico. Considering what I have pointed out in the previous section, based on Rojas, difference is thereby transformed into an epistemological, rather than an ontological one: Carro-Ripalda and Astier's argument is implicitly based on the assumption that, under the right conditions, difference can be translated into something that can be communicated to, and discussed with, other stakeholders. But the term 'ontological incompatibility' that the authors themselves use indicates there is something else at play, which cannot easily be translated: the nature of the relation of smallholder producers to their 'land, seed, crop, climate...as told and understood by themselves'; the 'central place' that Maize continues to occupy in Mesoamerican pre-Hispanic cosmology, and 'the social and cultural significance' that goes along with that. 58

Carro-Ripalda and Astier's emphasis on the problem of the dominant discourse, and the overarching Mexican structures of domination this discourse is related to (such as the 'neoliberal vision of the Mexican agricultural future' ${ }_{59}$ ), makes it occasionally difficult to understand what the problem of 'ontological incompatibility' really is about. At the end of the article, the place of the smallholder producers whom they have engaged seems once again clearly delineated and knowable: at stake for smallholders are, Carro-Ripalda and Astier argue, 'their lives as maize cultivators, their pride in their craft and knowledge, and

54 Carro-Ripalda and Astier, op.cit.

55 Ibid., p. 656.

56 lbid., p. 660.

57 Ibid., p. 659

58 Carro-Ripalda and Astier, op.cit., p. 659; Susana Carro-Ripalda, Marta Astier and Patricia Artía, "An Analysis of the GM Crop Debate in Mexico", in Phil Macnaghten and Susana Carro-Ripalda (eds.), Governing Agricultural Sustainability: Global Lessons from GM Crops (London and New York: Routledge, 2016), p. 34.

59 Carro-Ripalda and Astier, op.cit., p. 658. 
their ceremonially demanded right to information, choice and access to their "own resources"'. It is not just about 'retaining "traditional" ways of agriculture', as the anti-GMO movement maintains, but also about claiming 'political, economic and socio-cultural rights.' 60 Though this certainly adds a significant dimension to the debate, it indeed simply seems to add to, rather than radically challenge, the frameworks that are conventionally used in the anti-GMO debate, as well as the frameworks that focus on how to bring out and represent other people's 'voices' in a better way. Is this simply unavoidable when it comes to the production of academic knowledge through/in academic writing? As already indicated in the previous section, academic writing pursues by definition the objective of enhancing knowledge and providing improved insight into a certain situation. In its very structure, an academic piece of work aims to resolve and settle, rather than to dislocate, to destabilise, or to provide discomfort.

Carro-Ripalda and Astier's article is meant to render legible their own encounter of ontological difference for an academic audience. Is it possible for the reader to dig below these representational strategies, and to relate more directly to their encounter of what they themselves call ontological incompatibility? And which has led them to brand their final workshop, in a quite un-academic way, as a 'failure'? There are a few places in the article in which their inability to put into words and arguments all of 'the complexity of experiences, relations and reasons that bind people to maize' ${ }_{61}$ is more obvious. Becoming attuned to this complexity is linked to the authors having to become at least 'partially connected' - to yet again use de la Cadena's phrase - to the relations they attempt to trace. It is interesting, for example, that Carro-Ripalda and Astier talk about 'voices' as going beyond the semantic level, as conveying something acoustically, and as requiring a form of listening that shies away from asking pre-given questions. It is also interesting that some of that took place when they literally walked together with their interlocutors; precisely as it is emphasised by Blaney and Tickner:62

'Despite the shortcomings of the workshop...we felt that that, through our research on the ground, we had engaged with male and female farmers, heard about their perspectives on GM and their visions of a rural future, and accompanied them to work in milpas and markets. So, what do smallholder farmers' voices sound like? What meanings did they convey to us? We will provide here but a few of those sounds and meanings...' 63

Despite returning to the idea of voices as conveying 'meaning' in this quote, meaning is related to sounds, to walking together, to particular places with their own sounds, smells, and colours. The sample of actual 'voices' Carro-Ripalda and Astier then choose to present yet again invoke an intricate sense of the relationality of farmers and nonhumans:

'It is a joy to plant, getting hold of the maize, of a beautiful cob which is pleasant, to go to the harvest, to look at pretty cobs, all regular. Because this is what sustains me.'

'You can see the difference in the seeds straight away...You need to look at the cob and as soon as I grab it I see the difference.'

'It is the person who knows the seed the one who chooses it [for replanting the following year].64

By contrast, GM maize is associated by the smallholders whom Carro-Ripalda and Astier cite with feelings of 'artificiality, estrangement and distrust towards the created object (the GMO) in itself, not only because of deep ontological considerations... but because of the

60 Ibid., p. 662.

61 Ibid., p. 660.

62 Blaney and Tickner, op.cit., p. 308.

63 Carro-Ripalda and Astier, op.cit., p. 660; emphasis added.

64 All quoted in Ibid., pp. 660-661. 
political and economic motives which are "assembled" into it.' 65 Although the authors make a distinction between ontology and politics/economics here, their invoking of the 'assemblage' precisely shows how the latter becomes part of ontology itself, and then (as in the case of Hetherington) impacts on the sensual, bodily connection with the maize.

Understanding the relation between 'things' in this way allows for an analysis of power and domination that has at least the potential of moving beyond pre-given frameworks; strategically suspending them in order to 'sharpen [the] analysis of exactly how power operates, how relations are made and undermined, and with what consequences'.66 Genetically modified maize is a problem because it is part of particular Mexican neoliberal visions and strategies, but in the context outlined by Carro-Ripalda and Astier, that vision is not only (and not even primarily) made sense of through given frames of knowledge, such as Marxist theories of the exploitation of labour, but sensually, through the way it disrupts the (physical) pleasure and joy that has sustained the farmer-maize-assemblage so far.67 GM technology externalises the maize from farmers and estrange them from their ways of life; and it is only through this externalisation that GM maize becomes perceivable as a potential source of 'contamination', as a danger against which farmers need to 'defend' their seeds. 68

Now, some might counter that the previous paragraph in practice only provides a fancy repackaging of the two well-rehearsed arguments brought forward by many anti-GMO activists: (a) that the problem of GMOs is an intrinsic property that makes it 'unsafe' (which activists try to scientifically prove), and/or (b) that the fundamental problem of agricultural biotechnology is that it estranges farmers from their traditional, ancestral way of life, that it allows for their exploitation, and that it provides a further foothold for neoliberal visions of how the world should be ordered. Both arguments are grounded in modern ontology: the first goes down the route of science (contesting 'facts' about the 'nature' of GMOs on the basis of science itself), while the second goes down the 'social' route by either making a case for the need to respect cultural multiplicity, or for the need to prevent economic exploitation. Some activists make use of all of these routes and arguments. Famous environmental activist and intellectual Vandana Shiva, for example, determines the alienating character of the GMO to be an intrinsic property, while at the same time depicting smallholder producers as intrinsic "'reservoirs" of local or indigenous knowledge or as "natural" conservators of biodiversity through their traditional practices'. ${ }_{69}$ According to Carro-Ripalda and Astier, this 'unwittingly reinforce[es] images of smallholder producers as passive, timeless and voiceless.' 70 This leads to precisely the sort of romanticised reification of 'difference' that I have critiqued in the previous section of this article paradoxically, in this case, on the basis of an ontology that is deeply modern, as it regards both 'things' and 'people' as ontologically stable and classifiable.

65 Ibid., p. 661.

66 Emilie Cameron, Far Off Metal River: Inuit Lands, Settler Stories, and the Making of the Contemporary Arctic (Vancouver and Toronto: UBC Press, 2015), p. 26.

$67 \mathrm{My}$ knowledge of the situation is limited to what Carro-Ripalda and Astier convey. Sense-making strategies of the situation might well have involved the use of Marxist-related theories, as is often the case in Latin America. Cf. Lara Coleman, "Ethnography, Commitment, and Critique: Departing from Activist Scholarship", International Political Sociology, Vol. 9, No. 3, pp. 263-280; Lara Coleman/Doerthe Rosenow in Leonie Ansems de Vries et al., "Fracturing Politics (or, How to Avoid the Tacit Reproduction of Modern/Colonial Ontologies in Critical Thought", International Political Sociology Vol. 11, No. 1 (2017), pp. 90-108.

68 Carro-Ripalda and Astier, op.cit., p. 658.

69 Ibid., p. 658. Cf. Vandana Shiva, “Pests, Pesticides and Propaganda: The Story of Bt Cotton” (October 2015), available at: http://vandanashiva.com/?p=317 (accessed 2 March 2018); Vandana Shiva, Seeds of Suicide: the Ecological and Human Costs of Globalization of Agriculture (Delhi: Research Foundation for Science, Technology and Ecology, 2000).

70 Carro-Ripalda and Astier, op.cit., p. 658. 
By contrast, the authors of the two texts I have analysed in this section trace ontological encounters that cannot be contained by the nature/culture dichotomy. There is no pre-given (social) theory of neoliberalism and global power relations that dictates how the 'voice' of the farmer needs to be made sense of. There is also no pre-given understanding of the 'factual' (scientific) nature of GMOs. The notion of radical difference that comes up in these two texts emerged from precisely the 'misunderstandings' that the encounter of ethnographers with 'other people' and their relations brought to the fore; but importantly, it did not make any clearer to the ethnographer what the 'stuff' that grounded the misunderstandings is actually composed of. 71 Yet, somewhat paradoxically, despite all this emphasis on misunderstandings, incompatibility, grappling, failure, and critical selfreflection of one's own assumptions - at the end of the day what is left for the readers (at least if they do not explicitly focus on the 'ethnographic excess' found in the writings) is the impression that they know more about 'stuff' than they did before: that they understand the situation better, that new knowledge has been produced, that the object of analysis is more transparent than it has been before. How can this subjugation of the encountered ontologically difference to academic strategies of comprehensive sense-making avoided (if at all)?

This article itself is now coming up to what would normally be a conclusion - i.e. the treacherous waters of nailing its contribution to knowledge. Given that this article is yet again another 'third-level' engagement with questions of ontology and decoloniality, the question is whether there is any way to avoid this pull of hegemonic modes of academic knowledge production. Rather than providing a conclusion and reiterate the core argument that the article has made, I will attempt to finish this piece by raising even more questions, and by providing some further reflections.

\section{Turtles all the way down: (further) reflections on what questions to ask}

The pull of hegemonic systems of academic knowledge production is difficult to avoid. This is the case even in writings that are directly based on ontological encounters and controversies, and that reflect on the displacement that encountering different ontologies has entailed. But as I have indicated, this problem is even more pronounced in writings - like my own - that provide what I have previously called 'third-level' sense-making of ontological encounters.

The contribution of third-level analysis is usually a conceptual one, which makes it by definition veer towards the general and abstract rather than the concrete. In relation to the literature on decolonial thought and the ontological turn, this becomes manifest in three different (yet interrelated) ways: first, in the desire to provide an understanding of ontology that enables a conceptualisation of the former as multiple. Drawing on the work of Mario Blaser and Eduardo Viveiros de Castro respectively, Rojas and Blaney and Tickner argue that ontology can be thought of as multiple if reality is understood as always being 'enacted' or 'performed'. 72 This is what Blaser calls an understanding of ontology as 'material-semiotic': one that defines reality as 'always in the making through the dynamic relations of hybrid assemblages'.73 Pinpointing it like this is inevitably geared towards answering the question of what reality as such, in general is about. Secondly, there is an ambition to coin the general normative-political project that arises out of this understanding with a singular concept,

71 de la Cadena, op.cit., p. 63.

72 Rojas, op.cit., p. 378; Blaney and Tickner, op.cit., p. 303.

73 Mario Blaser, "Ontological Conflicts and the Stories of People in Spite of Europe: Towards a Conversation in Political Ontology", Current Anthropology, Vol. 54, No. 5 (2013), pp. 551-552. 
such as the pluriverse. Thirdly, arguments about ontological multiplicity and the emancipatory-decolonial political projects that arise out of its recognition are written for an audience of a particular discipline, such as IR: the aim is to provide a wholesale, general rethinking, or, indeed, 'reconstruction' of the latter.74

What sort of questions drive conceptual work into that direction, and what desire 'to know' underlies the questions? According to Cherokee philosopher Brian Yazzie Burkhart, for Native Americans 'the questions we choose to ask are more important than any truths we might hope to discover in asking such questions'. 75 By contrast, Western knowledge is always (at least in the mainstream) propositional knowledge: "knowledge of the form "that something is so"'. Here, knowledge cannot be verified by referring to direct experiences: 'there must be something underlying them and justifying them'. ${ }^{76}$ Burkhart gives the example of the 'routine response' given by 'Western people' to Indigenous accounts of creation: 'In [one] account, the earth rests on the back of a turtle. The Western response to this account is simply the question, "What holds the turtle?"' This question makes no sense to the Native storyteller, because the truth of the story lies in the paths to rightful action that it outlines, rather than what it has to say about the 'reality' of the world. But when the Westerner insists on the question, the answer finally is: "'Well, then there must be turtles all the way down".'77

Equating Rojas' and Blaney and Tickner's work with European mainstream (hence analytic) philosophy seems, at first glance, incredibly unfair. After all, those authors precisely advocate the cultivating of knowledge by direct awareness or acquaintance in exactly the way that Burkhart identifies as typical for Native Americans. But on the other hand, the framework that circumscribes their emphasis on the need for 'concreteness' is still an abstract one that wants to answer the question of how things really are and should be: enacted, performed, pluriversal, ... The point is not whether this argument about reality and politics is right or wrong. The point is to recognise that it is driven by particular questions that might make no sense in the context of other intelligence systems, but that need to be addressed in an academic article in order to make a conceptual argument compelling, convincing and original for an audience that primarily sits (whether it likes it or not) within a Western, colonial, hegemonic system of knowledge production. 78 And even when the contribution to knowledge production is not primarily conceptual, as in the 'second-level' work that I have analysed in the previous section in relation to the GMO controversy, the final argument that is made (e.g. about peasants' economic and cultural rights) is yet again lucid and comprehensible to an audience that seeks to comprehend 'stuff' within modern parameters.

Where to go from here (particularly as a white, European scholar)? As suggested by Tucker, one way might be to engage in much more direct, ethnographic research, which would enable more direct experience of ontological encounters. Despite previously-mentioned problems of even that research not going far enough, there is without doubt more space for providing a sense of grappling and dislocation if the originality of a piece of work is not purely grounded in the conceptual contribution it aims to make. However, not every scholar is able - body-, context- or funding-wise - to spend extensive periods of time in different

74 See Tucker, op.cit., p. 216, for a related critique.

75 Brian Yazzie Burkhart, "What Coyote and Thales Can Teach Us: An Outline of American Indian Epistemology", in Anne Walters (ed), American Indian Thought: Philosophical Essays (Maldon, Oxford and Carlton: Blackwell Publishing, 2004), p. 16. It could be argued that to talk about 'American Indians' or 'Native Americans' in this generic sense is problematic, but I am taking the lead from the author here.

76 lbid., p. 19; emphasis added.

77 Ibid., p. 20.

78 Cf. Cusicanqui, op.cit. 
places, and the ethical and political pitfalls of researching 'radical difference' through fieldwork with - but often rather on - others have been pointed out by Indigenous scholars numerous times. 79

But even for those unable or unwilling to do more primary, empirical research, there is space to push the boundaries of what can and should be written about (and how). For decades there have been attempts to provide 'innovative' platforms, for example at conferences, to talk about 'stuff' in different ways (e.g. through storytelling or artistic practices; not at least by e.g. Indigenous peoples themselves 80 ). However, these 'innovations' are still at the margins, and they will most likely never be able to compete with acknowledged knowledge production outlets such as journal articles and scholarly books. But even within the latter, there is always at least some space to push for more openendedness, more reflection on the author's embodied positionality, more auto-critique, more uncertainty and grappling (even if this is based on reading about the ontological encounters of others).

Although this sort of embodied self-reflection on a writer's 'situatedness' (which in my own case means being 'on the colonising side of a divide' ${ }^{81}$ ) has obviously been advanced by many critical scholars for decades (including feminists and post- as well as decolonial scholars), this article has hopefully shown that there is still (always) a need to go further, in order to more fundamentally challenge hegemonic, modern/colonial modes of knowledge production. The sense of unease that I have outlined in section two was particularly strong when reading conclusions that were geared towards making recommendations for the discipline of IR, or for 'international politics', as such. Aiming to make generic conclusions for entire disciplines, political fields, or global 'issues' pushes the generality and abstraction of a contribution even further away from an advocacy of the concrete. Why, and to whom, does it matter whether IR, as a discipline, or international politics, as object of study, becomes more pluriversal or not? What are the actual benefits of the concept of the pluriverse in the first place? Or to pick up the theme of this special issue: why does it matter whether IR is, or should move into, a mode of affirmation rather than critique? ${ }_{22}$ Why is this a good question to ask - and for whom?

This is not just a theoretical problem, but it has real-life consequences for actually-existing decolonial struggles. The desire for making a generic argument about relational ontologies and a pluriversal politics harbours the danger of making a huge variety of demands and struggles that often exist in tension and contradiction with each other commensurable. Indigenous demands for the repatriation of 'their' land might be at odds with the social justice demands for redistribution and 'the commons'. 83 For Blaney and Tickner, decolonial thought is commensurable with not just the ontological turn literature, but also feminist and other critical interventions.84 Mignolo and Arturo Escobar advocate a transnational fight for global justice and are enthusiastic about the potential of global movements to achieve that aim together. 85 Like Mignolo, Rojas explicitly draws on the World Social Forum slogan 'Another world is possible' as well as the Zapatistas slogan of 'a world where many words fit' to make her case about the need for a pluriversal understanding of emancipatory-decolonial

79 See e.g. Linda Tuhiwai Smith, Decolonising Methodology: Research and Indigenous Peoples, $2^{\text {nd }}$ ed. (Zed Books, 2012).

80 See e.g. Hunt, op.cit.

81 Last, op.cit., p. 65.

82 Suvi Alt, "Conclusion: Critique and the Politics of Affirmation in International Relations", Global Society, Vol. 33, No. 1 (2019).

83 Tuck and Yang, op.cit., pp. 23-28.

84 Blaney and Tickner, op.cit., p. 395.

85 See e.g. Mignolo, Local Histories, op.cit.; Arturo Escobar, "Beyond the Third World: Imperial Globality, Global Coloniality and Anti-Globalisation Social Movements", Third World Quarterly, Vol. 25, No. 1 (2004), pp. 207-230. 
politics. 86 While it can be argued that this problem of seeing all these struggles and demands as commensurable goes back to a lack of actual engagement with particular decolonial practices and battles, what I have argued in this article is that it is also related to the problem of how and what sort of knowledge is produced and valued in the Western academy: knowledge that is abstract, generic, and applicable beyond a specific context. Knowledge that is driven by the desire to know what is. Knowledge that desires to know what holds the turtle - all the way down.

86 Rojas, op.cit., p. 374. 